\title{
Mi
}

\section{Regulatory Complexity and Policy Uncertainty: Headwinds of Our Own Making}

\author{
Steven J. Davis* \\ Economics Working Paper 15118 \\ HOOVER INSTITUTION \\ 434 GaLVEZ MaLL \\ STANFORD UNIVERSITY \\ STANFORD, CA 94305-6010
}

December 2015

The U.S. regulatory system has grown increasingly expansive, intrusive and complex in recent decades, its tax system has become ridiculously complicated, and its economic policies have become less predictable. I present several pieces of evidence related to these developments and discuss some of their costs. I then sketch some ideas to arrest or reverse these developments. In this regard, I stress the importance of simplicity in regulatory design, the advantages of policy designs that foster predictable regulatory responses, and the need for new institutions to restrain ineffective, excessively burdensome and capricious regulations.

This paper was prepared to accompany remarks delivered at the Hillsdale College Free Market Forum on "Markets, Government, and the Common Good" in Omaha, Nebraska on 15-17 October, 2015.

*William H. Abbot Professor of International Business and Economics, University of Chicago Booth School of Business, and Visiting Fellow at the Hoover Institution, Stanford University. Webpage: http://faculty.chicagobooth.edu/steven.davis/.

The Hoover Institution Economics Working Paper Series allows authors to distribute research for discussion and comment among other researchers. Working papers reflect the views of the author and not the views of the Hoover Institution. 


\section{Three Principles for a Vibrant Economy}

In his essay on how the United States can "Return to a Vibrant Economy," George Shultz (2013) offers several worthy principles to guide policy makers. Here are three of them:

1. Keep the regulatory system clear, simple, and easy to administer, and then live with it.

2. Keep the tax system as simple as possible. ${ }^{1}$

3. Make economic policies predictable.

Let's review the U.S. situation in relation to these principles, starting with the regulatory system.

\section{Aspects of the U.S. Situation}

\section{A. Regulatory Overreach}

Figure 1 shows page counts for the Code of Federal Regulations (CFR), which compiles all federal regulations in effect each year. The CFR grew nearly eight-fold over the past 55 years, reflecting tremendous growth in the scale and complexity of federal regulations. At 175,000 pages, the CFR contains as many words as 130 copies of the King James Bible. ${ }^{2}$ While Ten Commandments sufficed for the Hebrew God of the Old Testament, the CFR contains about one million commandments in the form of "shall," "must," "may not," "prohibited," and "required."3

Figure 1 strongly suggests that the regulatory leviathan is a bipartisan creation: The regulatory code consistently grew during both Democratic and Republican presidencies. There are exceptions - the first term of Ronald Reagan, and the first term of Bill Clinton, for example but they are few and short-lived. This observation carries an important corollary: Simply putting one political party or the other in charge of the federal government is unlikely, by itself, to

\footnotetext{
${ }^{1}$ Shultz (2013, p. 42) advised "Keep tax rates as low as possible and keep the tax system as simple as possible." Insofar as a simple tax system means few deductions and a broad tax base, simplicity facilitates lower tax rates.

${ }^{2}$ See Patrick McLaughlin's “The Code of Federal Regulations: The Ultimate Longread" at http://mercatus.org/publication/code-federal-regulations-ultimate-longread-game-throneshunger-games.

${ }^{3}$ See Al-Ubaydli and McLaughlin (2014).
} 
reverse or permanently arrest the expansion of the regulatory state. We need a more fundamental shift in our approach to regulation.

It's hard to summarize the scale of state and local government regulation, or its growth over time. Consider, instead, just one example in this regard: occupational licensing. The fraction of workers who must hold a government-mandated license to lawfully perform their jobs rose from less than 5 percent in the 1950 s to 29 percent in $2008 .^{4}$ About one-third of growth in occupational licensing since the 1960 s reflects changes in the mix of jobs. ${ }^{5}$ The other two-thirds reflects a greater prevalence of licensing requirements within occupations.

Licensing requirements make sense in a few occupations, as a means to protect people from unscrupulous or incompetent providers. But do we really need onerous licensing requirements for barbers, manicurists, tree trimmers, funeral attendants, massage therapists, auctioneers, sign language interpreters, and hundreds of other jobs? ${ }^{6}$ Worker certification, which preserves consumer choice and competition among suppliers, is usually a better response to concerns about supplier quality. All too often, licensing serves mainly to protect incumbent businesses and workers from competition - to the detriment of customers, young workers, and would-be entrepreneurs.

\footnotetext{
${ }^{4}$ See Kleiner and Krueger (2013). Carpenter et al. (2012) provide an illuminating description of state licensure requirements in 102 low- and moderate-income occupations. Kleiner (2015) and U.S. Department of the Treasury Office of Economic Policy (2015) provide useful analyses of occupational licensing in the United States, discussions of costs and benefits, and recommendations for reforms. Davis and Haltiwanger (2014) discuss a broad range of factors, including occupational licensing, that contributed to declines in U.S. business dynamism and labor market fluidity in recent decades. They also provide evidence that these developments led to lower employment rates, especially for younger and less educated persons.

${ }^{5}$ U.S. Department of the Treasury Office of Economic Policy (2015), page 20.

6 These examples are drawn from Table 1 in Carpenter et al. (2012). According to estimates from the Council of State Governments, "over 1,100 jobs were licensed, certified, or registered in at least one state.” (U.S. Department of Treasury Office of Economic Policy, 2015, page 7)
} 
To be sure, some expansion of the regulatory state can be seen as an efficient, welfareenhancing response to rising populations and real incomes, and to the increasing complexity of our economy and society. ${ }^{7}$ But I find it impossible to see the current U.S. system as an approximately efficient regulatory response to the complexities of modern life. If occupational licensing is really about consumer protection, why does the average cosmetologist spend 372 days in training to obtain a government-mandated license, while the average emergency medical technician spends 33 days? ${ }^{8}$ To take another example, does anyone believe that regulatory resistance to Uber's ride-sharing service is truly motivated by a concern for consumer welfare?

International comparisons reinforce concerns about U.S. regulatory overreach. According to the World Bank's latest Doing Business report, the United States ranks $47^{\text {th }}$ out of 189 countries in the ease of starting a new business. ${ }^{9}$

\section{B. A Byzantine Tax Code}

The size and complexity of the U.S. tax code also grew dramatically in recent decades. ${ }^{10}$ As of 2011, it takes 70,000 pages of instructions to explain the federal tax code (McCaherty, 2014). The code has about four million words and 67,000 sections, subsections and cross-references. ${ }^{11}$ It's all crystal clear if you read the instructions carefully. However, you will need to reread every year to stay current. There were about 4,400 changes to the tax code from 2000 to 2010 , 579 changes in 2010 alone. ${ }^{12}$ As the Internal Revenue Service's own Taxpayer Advocate

\footnotetext{
${ }^{7}$ See, for example, Mulligan and Shleifer (2005) and Shleifer (2010). In contrast, Tabarrok and Cowen (2015) argue that increasingly easy access to information about product quality, worker performance and business reputations undermines the traditional case for many forms of economic regulation.

${ }^{8}$ Carpenter et al. (2012).

${ }^{9}$ World Bank (2014), page 227.

${ }^{10} \mathrm{See}$, for example, the discussions in Joint Committee on Taxation (2001) and National Taxpayer Advocate $(2012,2014)$.

${ }^{11}$ National Taxpayer Advocate (2014, Volume I, page 104).

${ }^{12}$ National Taxpayer Advocate (2012, Volume I, page 4).
} 
laments, "Individual taxpayers find return preparation so overwhelming that about 94 percent of them used a preparer or tax software in processing year 2013." 13

To a large extent, the personal and corporate income tax codes are ludicrously complex because policy makers (and citizens) insist on using them to favor certain activities and groups and disfavor others. This fact is evident in the enormous volume of "tax expenditures" - tax revenues foregone because of rules that grant tax breaks under particular conditions and for certain taxpayers. The Taxpayer Advocate estimates that fiscal year 2015 tax expenditures amount to about $\$ 1.4$ trillion. $^{14}$ By way of comparison, all direct federal spending was about $\$ 3.5$ trillion in 2014.

Aside from the sheer complexity of its tax system, the United States fares poorly compared to other countries in terms of tax burdens on business activity - young businesses, in particular. Djankov et al. (2010) gather comparable data for 85 countries to compute effective tax rates on corporate profits for a successful, mid-size startup business engaged in light manufacturing and retail activity. For the United States, they compute an effective five-year tax rate of 32 percent. That places the United States third from the bottom, just ahead of Pakistan. ${ }^{15}$

\section{A Drift Away from Predictable Policies}

Figure 2 plots a newspaper-based index of economic policy uncertainty (EPU) for the United States that I developed with Scott Baker and Nick Bloom. ${ }^{16}$ Our EPU index relies on frequency counts of newspaper articles that contain terms pertaining to the economy, policy and

\footnotetext{
${ }^{13}$ National Taxpayer Advocate (2014, Volume I, page 104). For a review of research on taxpayer compliance costs, see Fichtner and Feldman (2013).

${ }_{15}^{14}$ National Taxpayer Advocate (2014, Volume I, page 104).

${ }^{15}$ For additional discussion of U.S. corporate tax burdens in comparison to other countries, see Hassett and Mathur (2009).

${ }^{16}$ See Baker, Bloom and Davis (2015).
} 
uncertainty. ${ }^{17}$ The index shown in dark blue rises by a factor of more than five from the mid 1960s to the 2010-2012 period, which points to a large upward drift in concerns about policyrelated economic uncertainty - at least as perceived by newspaper journalists, and presumably by their readers as well. ${ }^{18}$

A potential concern about this inference involves possible changes over time in newspaper topical coverage. Perhaps, for example, newspapers gradually shifted coverage to articles about economic matters for reasons apart from greater policy uncertainty per se. That concern motivates an alternate version of the index, shown in light blue, which scales the frequency of EPU articles by the frequency of articles about economy, business, industry and commerce. The alternate EPU index rises by a factor of nearly four from 1965 to 2012 . In other words, there has been a large increase in the share of newspaper articles about policy-related uncertainty among those articles that discuss matters of economics, business and commerce.

Other evidence also supports the face-value interpretation of Figure 2. My coauthors and I find more frequent Beige Book discussions of policy-related uncertainty in recent years, especially from 2010 to 2014. This pattern indicates that Beige Book survey respondents and interviewees - business people, market experts, economists, and the like - also perceive higher levels of policy uncertainty in recent years. Our newspaper-based EPU index for the United Kingdom shows no secular drift over the past 50 years, in sharp contrast to the U.S. experience. The U.K. evidence says there was no general tendency for English-language newspapers to

\footnotetext{
${ }^{17}$ In constructing our EPU index, we scale the frequency of articles about economic policy uncertainty by the number of all articles in the same newspaper and month. The EPU index in Figure 2 is from Baker et al. (2014). The version in Baker, Bloom and Davis (2015) - and available at www.PolicyUncertainty.com - adds "war" and "tariff" to the policy term set, a modification that matters little after World War II.

${ }^{18}$ Baker et al. (2014) point to the expansion of government involvement in the economy and rising political polarization as potential drivers of the upward drift in U.S. policy uncertainty.
} 
devote increasing attention to policy-related uncertainty irrespective of actual developments. In John Taylor's (2012) account, U.S. policy became more interventionist in the 1960s and 1970s, shifted to a more rules-oriented approach in the 1980s and 1990s, and then swung back to more discretionary, less predictable policies after the early 2000s. Taylor's characterization is roughly in line with the alternate index (light blue) in Figure 2.

\section{Uncertainty about Healthcare Policy, Financial Regulation and Tax Policy}

My work with Baker and Bloom also develops category-specific EPU indices. Our approach is simple: Within the set of newspaper articles that discuss policy-related economic uncertainty, we identify and quantify those that discuss particular areas of policy such as national security, monetary policy, tax policy, and so on. I consider healthcare policy, financial regulation and tax policy here. Our 2015 paper contains additional discussion, and our website at www.PolicyUncertainty.com provides data for eleven policy categories, with regular updates.

Figure 3 displays our Healthcare Policy Uncertainty Index. ${ }^{19}$ Three episodes stand out: First, the failed healthcare reform initiative in the first term of President Clinton. Second, President Bush's Medicare reform initiative announced in his January 2003 State of the Union Address, which led to passage of the Medicare Prescription Drug Act of 2003. And third, the Affordable Care Act (ACA), which involved several years of intense legislative and electoral battles, uncertainty about its economic effects, doubts about its political durability, close-call constitutional challenges, and major implementation snafus. These ACA-related developments brought much higher levels of healthcare policy uncertainty and greater volatility.

\footnotetext{
${ }^{19}$ We use the following terms to construct the Healthcare Policy Uncertainty Index (in addition to requiring an article to meet our Economic, Policy and Uncertainty criteria): health care, Medicaid, Medicare, health insurance, malpractice tort reform, malpractice reform, prescription drugs, drug policy, Food and Drug Administration, FDA, medical malpractice, prescription drug act, medical insurance reform, medical liability, part d, Affordable Care Act, Obamacare.
} 
Figure 4 displays our Financial Regulation Uncertainty Index. ${ }^{20}$ It peaked with the fullforce eruption of the financial crisis in September $2008,{ }^{21}$ which led monetary policymakers and financial regulators to undertake a series of extraordinary responses unlike anything seen in the United States since the 1930s. Other prominent episodes of elevated uncertainty about financial regulation include the period surrounding passage of the Sarbanes-Oxley Act in July 2002, the Dodd-Frank Act of 2010, and the presidential election contest between Barack Obama and Mitt Romney, who offered starkly different views about financial regulation and economic policy more generally.

My work with Baker and Bloom concludes that tax policy is the single largest source of elevated U.S. policy uncertainty in recent years. Evidence for this claim emerges clearly in our content analyses of newspapers and the Fed's periodic Beige Book releases. Figure 5 provides another type of evidence about the nature and evolution of U.S. tax policy uncertainty. ${ }^{22}$ It shows an enormous upswing after the early 2000s in the (discounted) dollar volume of tax code provisions set to expire in the future. These provisions are a source of uncertainty because

\footnotetext{
${ }^{20}$ We use the following terms to construct the Financial Regulation Uncertainty Index: banking (or bank) supervision, Glass-Steagall, TARP, thrift supervision, Dodd-Frank, financial reform, Commodity Futures Trading Commission, CFTC, House Financial Services Committee, Basel, capital requirement, Volcker rule, bank stress test, Securities and Exchange Commission, SEC, deposit insurance, FDIC, FSLIC, OTS, OCC, FIRREA.

${ }^{21}$ The monthly version of the Financial Regulation Uncertainty Index jumped from 92 in August 2008 to 878 in September and 730 in October.

${ }^{22}$ Figure 5 is an improved version of the tax code expirations index in Baker, Bloom and Davis (2012) and early drafts of our 2015 paper. To construct the figure, we draw on Congressional Budget Office sources that list federal tax code provisions scheduled to expire over the next ten years and their projected revenue effects. Specifically, in any given year, we compute the absolute dollar value of expiring tax code provisions for the current and next ten years, discount future expirations at a 50 percent annual rate, and sum the discounted absolute revenue effects over the current and next ten years. We apply a high discount rate on the view that uncertainty about tax code provisions set to expire in the out years are unlikely to be a major source of current concern.
} 
Congress has often waited till the last hour before deciding whether and how to actually let them expire, undermining the predictability of tax rates and revenues.

A clear and important example involves the Bush-era tax cuts initially set to expire at the end of 2010. As the original expiration date grew closer, Democrats and Republicans staked out opposing positions about whether to preserve or reverse the tax cuts and, if so, for which taxpayers. Rather than resolving the uncertainty in advance, Congress waited until mid December 2010 - only two weeks before new tax rates were set to take effect - before passing the Tax Relief Act and extending the Bush rate cuts for all taxpayers. Even this uncertainty resolution was limited and short-lived, because Congress extended the rate cuts for only two years. That set the stage for what became an even higher-stakes political battle over the so-called "Fiscal Cliff" in late 2012. ${ }^{23}$ This time around Congress waited until the early hours of 2013 to resolve the uncertainty about 2013 tax rates and projected tax revenues.

Looking at Figure 5, we see a tiny volume of discounted tax expirations before 2003, a bump in 2003-2004 that reflects the expiration of accelerated capital depreciation allowances, greatly elevated levels from 2009 to 2012, and a very sharp drop off in 2013 that reflects the lastminute resolution of the Fiscal Cliff. The overall pattern shows a dramatic increase in temporary tax measures subject to continual renewal, debate and uncertainty. This heavy reliance on scheduled tax code expirations is a recent phenomenon in the U.S. policymaking process. It needlessly injects uncertainty into the economic environment facing households and businesses. Last-minute resolutions of political fights over the federal government's debt ceiling and threats to shut down large parts of the federal government have the same character. These practices

\footnotetext{
${ }^{23}$ Planned government spending cuts under the Budget Control Act of 2011 were also part of the Fiscal Cliff.
} 
undermine predictability in government policy, and they create a more challenging and uncertain economic environment for households and businesses.

\section{Taking Stock}

So how does U.S. policy measure up to the three Shultz principles for a vibrant economy? Poorly - and that's a charitable assessment. The regulatory apparatus has become increasingly expansive, intrusive and complex over time. The federal tax code has grown ridiculously complicated. Policy has become less predictable. ${ }^{24}$ Rather than embrace the Shultz principles, we have been marching away from them in haste.

These developments come at high cost. According to Crews (2015), the "best available" evidence and analysis suggest that regulatory compliance and economic costs are about $\$ 1.9$ trillion annually. Of course, it's hard to quantify the overall costs (and benefits) of government regulations. Perhaps the costs are smaller than suggested by Crews. Perhaps they are much larger, especially if regulations dampen growth in a manner that cumulates over time, as argued by Dawson and Seater (2013).

The good Catholic Sisters who saw to my moral instruction in primary school devoted many hours to the Ten Commandments. They wanted my classmates and me to avoid sins. Their success in that regard is in doubt. But at least the Sisters could be confident that we did not sin out of ignorance or uncertainty. How they would have instructed us on one million commandments, I do not know. The delinquents in my school found it hard to absorb a mere ten. There is a serious point here: The enormous scale and complexity of the regulatory system is

\footnotetext{
${ }^{24}$ I am hardly the first observer to reach a similar assessment. On the growing scale, complexity and intrusiveness of government regulations, see Crews (2015), Cochrane (2015) and Murray (2015), among many others. Proposals to address the complexity of the U.S. tax code go back decades; see, for example, Hall and Rabushka (2007), first edition published in 1985. Concerns about rising policy uncertainty are prominent in my earlier work with Baker and Bloom and in Taylor (2012), among others.
} 
itself a source of uncertainty about the law and about whether and how it will be enforced. Just staying on the right side of the law has become a much more challenging and burdensome undertaking.

The burdens fall more heavily on smaller and younger businesses, because compliance involves significant fixed costs and because young businesses have had less time to develop the knowledge and internal processes required for compliance. Partly for these reasons, our current regulatory and tax systems work to the disadvantage of entrepreneurship, young businesses and small businesses. Figure 6 shows the employment share of young businesses, defined as firms that hired their first paid employee within the past 60 months. The young-firm employment share fell by more than half in recent decades, from nearly 18 percent in 1981 to just over 8 percent in 2012. This drop in the young-firm share is pervasive across broad industry groups and U.S. states. $^{25}$ Although other factors are also in play, the growing scale and complexity of the regulatory system is suppressing the development of new businesses. ${ }^{26}$ That's a worrisome change in the U.S. economic landscape in recent decades.

While my remarks focus on the economic burdens of regulatory complexity, there is more at stake. John Cochrane (2015) argues that the dramatic expansion of the regulatory state also poses a danger to our political freedoms. He sees an "emerging threat of large discretionary regulation, used as a tool of political control.... Just who gets that visit from the EPA can have a powerful silencing effect."

Tax code complexity is costly as well, most obviously in the form of compliance burdens. Complexity also increases the distortionary effects of taxation on labor supply, consumption and investment decisions. A basic principle of least-harm taxation calls for a broad tax base with

\footnotetext{
${ }^{25}$ See Davis et al. (2006) and Decker et al. (2014).

${ }^{26}$ See Davis and Haltiwanger (2014, 2015), Liang et al. (2014) and Karahan et al. (2015).
} 
uniform tax rates. Tax expenditures do the opposite, shrinking the tax base and requiring higher, more distortionary tax rates for any given level of revenues. ${ }^{27}$ Tax system complexity also encourages the diversion of time and effort to socially unproductive activities - gaming the tax system, lobbying for tax rules that advance special interests, and the like.

There are also sound reasons for concern about the harmful effects of policy-related uncertainty. Because it's typically costly to reverse an investment or hiring decision, greater uncertainty naturally prompts businesses to pull back from capital expenditures and job creation. ${ }^{28}$ Uncertainty also raises financing costs, further discouraging investment and job creation. ${ }^{29}$ Weak investments in new technologies, capital goods, product development, and worker training undermine longer-run growth.

Motivated by this reasoning, my work with Baker and Bloom investigates the effects of policy uncertainty. Using firm-level data, we find that policy uncertainty raises stock price volatility and reduces investment and employment in policy-sensitive sectors like defense, healthcare, and infrastructure construction. At the macroeconomic level, we find that increases in policy uncertainty foreshadow declines in aggregate investment, output and employment in the United States and other large economies. In short, our results indicate that policy uncertainty hampers economic progress. As we discuss in our 2015 paper, many other studies also find evidence that policy uncertainty has negative economic effects.

\footnotetext{
${ }^{27}$ Because tax expenditures accrue disproportionately to persons with higher incomes, they work against tax system progressivity as well. See Congressional Budget Office (2013).

${ }^{28}$ See Bernanke (1983).

${ }^{29}$ See, for example, Pastor and Veronesi (2013) and Gilchrist et al. (2014).
} 


\section{What to Do?}

So how can we advance the three principles for a vibrant economy that I borrowed from George Shultz? I now sketch a few ideas in that regard. Again, I make no claims of originality on the contrary, I borrow freely from the good ideas of others.

Design for Simplicity: Policy design profoundly affects the complexity of the regulatory system, for good or ill. As an example, consider how the government might curtail carbon dioxide emissions. One approach is to issue pages upon pages of detailed regulations that specify how to design and operate power plants, corporate average fuel economy (CAFE) standards for automobiles, which fuel mix to burn in various types of vehicles, energy efficiency standards for home appliances, what type of light bulbs to use, and so on. The logic of this approach requires a rash of intrusive command-and-control regulations.

Another approach is to tax carbon emissions or fossil fuel consumption, the main source of carbon emissions. This approach lets people choose how to conduct their activities, but imposes a price on activities that emit carbon. It yields a much smaller, simpler regulatory apparatus (to establish a system for taxing carbon). By preserving free choice, it also improves the odds that some individual or business will develop new and better ways to economize on carbon emissions - ways not envisioned by the regulators. ${ }^{30}$ When that happens, the carbon tax gives others an incentive to adopt the new means to lower carbon emissions. As an added benefit, the revenues produced by a carbon tax can be used to lower other taxes.

Foster Predictable Regulatory Responses: Policy design can also foster or undermine predictable responses by regulators to adverse developments. To see this point, consider the

\footnotetext{
${ }^{30}$ See Mankiw (2013) for a fuller discussion of why carbon taxes make more sense than regulations as a means for curtailing carbon emissions. See Carbon Washington at http://carbonwa.org for an explicit proposal modeled after a successful carbon tax regime in British Columbia.
} 
phenomenon of "runs" by holders of short-term claims against financial institutions. Runs by bank depositors wreaked havoc in the early 1930s, presenting policymakers with difficult decisions about how to contain the resulting financial panic and the negative spillovers to the rest of the economy. In response, the United States introduced government-backed deposit insurance programs that largely eliminated runs by bank depositors, short-circuiting run-driven financial panics. For decades, most bank failures became orderly, almost routine, affairs.

Runs re-emerged in different forms and to devastating effect during the financial crisis of 2007-2009. When Lehman Brothers failed on 15 September 2008, the proximate trigger was its inability to continue rolling over the very short-term borrowings that funded much of its business. ${ }^{31}$ Effectively, its short-term creditors "ran" and left Lehman unable to meet its funding requirements, compelling the company to file for Chapter 11 bankruptcy protection and initiating a long and messy liquidation. The Lehman failure precipitated runs on other financial institutions, and the negative effects reverberated throughout the U.S. and global economies.

The Fed, the Securities and Exchange Commission and other regulators came under heavy criticism for letting Lehman fail and for their oversight of the company. The outright failure caught market participants by surprise, amplifying the ensuing uncertainty and sense of panic. But my goal here is not to judge how well the regulators did their jobs. Instead, I want to stress a different point: The United States lacks an effective legal process for resolving a distressed financial institution in the midst of a run by its short-term creditors. Partly for this reason, the regulators had no good option for responding to the Lehman situation. This weakness in our failure resolution process creates especially severe problems for regulators and private sector actors during a financial crisis, as in 2008 and 2009.

\footnotetext{
${ }^{31}$ Wiggins, Piontek and Metrick (2014) provide a useful discussion of the Lehman Brothers failure.
} 
Fortunately, there are some interesting proposals that aim to fix this problem. One proposal would add a new Chapter 14 to the U.S bankruptcy code, a chapter explicitly designed for run-prone financial institutions. ${ }^{32}$ Here's the basic idea: ${ }^{33}$

Chapter 14 could be implemented over a weekend, and it would leave operating subsidiaries outside of bankruptcy entirely. It would do this by moving the original financial firm's operations to a new bridge company that is not in bankruptcy. This bridge company would be recapitalized by leaving behind long-term unsecured debt (capital structure debt).

The aim is to let a failing financial firm go through bankruptcy in a predictable, rulesbased manner without spillovers while people continue to use its financial services, just as people flew on American Airlines planes, bought Kmart sundries and tried on Hartmax suits when those firms were in bankruptcy.

This proposal has teeth only to the extent that run-prone financial institutions hold a good deal of long-term debt. Thus, an effective version of this bankruptcy reform goes hand in hand with regulations that require certain financial institutions to hold sufficient long-term debt. If this proposal becomes law and works as advertised, large and systemically important financial institutions can undergo a failure and reorganization process without causing deadly harm to the larger financial system and the broader economy. The job facing regulators will also become immensely easier, and their responses to negative shocks will become more predictable.

Restrain the Regulators: Here's a common-sense recommendation - before introducing a new regulation (or when reviewing an existing one), a regulatory agency should clearly describe the problem it seeks to address, assess its significance, explain why regulation is a good response, provide a sound cost-benefit analysis for any proposed regulatory action, and explain why the proposed action is better than alternatives - including the alternative of no regulatory

\footnotetext{
${ }^{32}$ See Scott and Taylor (2012) and Scott, Jackson and Taylor (2015).

${ }^{33}$ Quoting from "Making Failure Feasible and Ending Too Big to Fail" at John Taylor's Economics One blog at http://economicsone.com/2015/07/29/make-failure-feasible-and-end-toobig-to-fail/. Accessed 14 October 2015.
} 
action. As it turns out, every president since Jimmy Carter has issued or reaffirmed executive orders broadly in line with this recommendation. ${ }^{34}$ And government agencies often carry out regulatory impact analyses that purport to implement some or all elements of this recommendation.

Unfortunately, regulatory impact analyses often fail to deliver as promised. ${ }^{35}$ Sometimes the reasons are technical, as when key costs and benefits are highly uncertain or hard to quantify. ${ }^{36}$ But there's a first-order institutional problem as well: the absence of an external authority that monitors the regulator to ensure high-quality, even-handed regulatory impact analyses, and that restrains the regulator when it oversteps or misapplies its authority.

When government agencies promulgate ineffective, costly or downright perverse regulations, recourse is difficult. In principle, Congress oversees the regulatory agencies, and courts ensure they operate within the boundaries of the law. In practice, Congress is too busy (or distracted) to provide effective oversight, administrative courts are creatures of the regulatory agencies, and the judicial process in the general courts is slow and costly. Resistance to bad regulations can entail enormous costs and risks for businesses and individuals. Pushing back against abusive, unsound or just-plain silly regulations often requires financial and other resources that are beyond the capacities of most businesses and individuals. So bad regulations proliferate and persist.

One way to restrain regulators would be to establish independent regulator oversight commissions (IROCs), with powers as follows. At its own initiative or at the request of affected parties, an IROC could review the adequacy and quality of regulatory impact analyses offered by

\footnotetext{
${ }^{34}$ See Ellig (2015).

${ }^{35}$ Ellig (2015) cites several studies that assess the quality and usefulness of regulatory impact analyses.

${ }^{36}$ See, for example, Fraas and Lutter (2011).
} 
the regulator in support of a regulation. If the IROC determined that the impact analysis was inadequate or incomplete, or that it did not support the case for the regulation under review, the regulation would be suspended. IROCs would have no power to make or modify regulations and, unlike courts, they would not rule on the legality of regulations. Their authority would be limited to suspending regulations that are not adequately supported by high-quality, even-handed regulatory impact analyses.

There are other worthy proposals to restrain the regulators. Charles Murray (2015) advocates an inspired combination of civil disobedience and cooperatively underwritten lawsuits to push back against pointless, stupid and tyrannical regulations. At least one presidential candidate advances other ideas for restraining the regulators. ${ }^{37}$

Here are other ways to further the Shultz principles for a vibrant economy:

- Devote greater attention to competent execution - sorely lacking in the roll out of health insurance exchanges under the Affordable Care Act, for example - to reduce the uncertainty associated with government policies and programs.

- Resist the use of executive actions on major policy issues as an end-run around the legislature. Legislative action may be hard to achieve, but by the same token it comes with broader political support and greater durability, lending predictability to policy.

- Martin Feldstein (2015) offers a sensible and politically workable approach to curtailing tax expenditures.

- Stop the deliberate injections of uncertainty in the form of debt-ceiling crises and lastminute fights over near-term tax rates.

\footnotetext{
${ }^{37}$ See "Regulatory Reform: The Regulatory Crisis in Washington," 22 September 2015 at https://jeb2016.com/the-regulatory-crisis-in-washington/, accessed 12 October 2015.
} 
Finally, we (citizens and policymakers) must recognize limits: Government action is not the right solution to every societal problem. And action at the federal level is not the right place to address every societal problem that calls for a government response. A government that does too much will do nothing well.

\section{Concluding Remarks}

These days, many of my fellow economists speak of headwinds that curtail the possibilities for growth. Yes, we face headwinds. But many of the headwinds are of our own making. We can unmake them, too. Or, better yet, turn them into tailwinds.

Some degree of regulatory complexity and policy uncertainty will be with us always. But their extent, and the weight of their burdens, depends greatly on policy design and our approach to regulation and taxation. There is no fundamental economic law that forces us to endure the growth-inhibiting effects of an overly complex, expansive and burdensome regulatory system. There is no fundamental economic law that compels us to live with a byzantine tax code. There is certainly no fundamental law that requires politically manufactured injections of uncertainty into the economic environment facing households and businesses. A course correction is overdue.

\section{References}

Al-Ubaydli, O and McLaughlin, P.A. 2015. "RegData: A Numerical Database on IndustrySpecific Regulations for All US Industries and Federal Regulations, 1997-2012.” Working Paper, Mercatus Center at George Mason University, Arlington, VA.

Baker, Scott R., Nicholas Bloom and Steven J. Davis, 2012. "Has Economic Policy Uncertainty Hampered the Recovery?" in Government Policies and the Delayed Economic Recovery, edited by Lee Ohanian, John B. Taylor and Ian Wright, Hoover Institution Press. 
Baker, Scott R., Nicholas Bloom and Steven J. Davis, 2015. "Measuring Economic Policy Uncertainty," NBER Working Paper No. 21633.

Baker, Scott R., Nicholas Bloom, Brandice Canes-Wrone, Steven J. Davis and Jonathan Rodden, 2013. "Why Has U. S. Policy Uncertainty Risen Since 1960?” American Economic Review, Papers \& Proceedings, 104, no. 5 (May), 56-60.

Bernanke, Ben S., 1983. "Irreversibility, Uncertainty and Cyclical Investment," Quarterly Journal of Economics, 97, no. 1 (February), 85-106.

Carpenter, Dick M., Lisa Knepper, Angela C. Erickson, and John K. Ross, 2012. License to Work: A National Study of Burdens from Occupational Licensing, Institute for Social Justice.

Cochrane, John, 2015. "The Rule of Law in the Regulatory State," prepared for "The Foundation of Liberty: Magna Carta After 800 Years," Hoover Institution conference, June 25.

Congressional Budget Office, 2013. "The Distribution of Major Tax Expenditures in the Individual Income Tax System," May.

Crews, Clyde Wayne, Jr., 2015. 10,000 Commandments, 2015 Edition: An Annual Snapshot of the Federal Regulatory State, Competitive Enterprise Institute.

Davis, Steven J. and John Haltiwanger, 2014. "Labor Market Fluidity and Economic Performance," in Re-Evaluating Labor Market Dynamics, Federal Reserve Bank of Kansas City. Also available as NBER Working Paper No. 20479.

Davis, Steven J. and John Haltiwanger, 2015. "Dynamism Diminished: The Role of Credit Conditions and Housing Markets," work in progress. Slides available at http://faculty.chicagobooth.edu/steven.davis/.

Davis, Steven, John Haltiwanger, Ron Jarmin and Javier Miranda, 2006. "Volatility and Dispersion of Business Growth Rates: Publicly Traded versus Privately Held Firms," NBER Macroeconomics Annual.

Decker, Ryan, John Haltiwanger, Ron S. Jarmin and Javier Miranda, 2014. "The Secular Decline of Business Dynamism in the United States," working paper, University of Maryland.

Dawson, John W. and John J. Seater, 2013. "Federal Regulation and Aggregate Economic Growth," Journal of Economic Growth, 18, 137-177. 
Djankov, Simeon, Tim Ganser, Caralee McLiesh, Rita Ramalho and Andrei Shleifer, 2010. "The Effect of Corporate Taxes on Investment and Entrepreneurship," American Economic Journal: Macroeconomics, 2 (July), 31-64.

Ellig, Jerry, 2015. "Regulatory Impact Analysis: Four Decades of Foibles," Mercatus Center, George Mason University, January.

Feldstein, Martin, 2015. "Raising Revenue by Limiting Tax Expenditures," in Jeffrey R. Brown, editor, Tax Policy and the Economy, 29.

Fichtner, Jason J. and Jacob M. Feldman, 2013. "The Hidden Costs of Tax Compliance," Mercatus Center, George Mason University.

Fraas, Art and Randall Lutter, 2011. "The Challenges of Improving the Economic Analysis of Pending Regulations: The Experience of OMB Circular A-4," Annual Review of Resource Economics, 3, 71-85.

Gilchrist, Simon, Jae W. Sim and Egon Zakrajsek, 2014. "Uncertainty, Financial Frictions, and Investment Dynamics,” NBER Working Paper 20038.

Hall, Robert E. and Alvin Rabushka, 2007. The Flat Tax, second edition. Hoover Institution Press.

Hassett, Kevin A. and Aparna Mathur, 2009. "Taxes Around the World: A Brief History of World Tax Policy," American Enterprise Institute.

Joint Committee on Taxation, 2001. Study of the Overall State of the Federal Tax System and Recommendations for Simplification (JCS-3-01), April.

Joint Committee on Taxation, 2015. Complexity in the Federal Tax System (JCX-49-15), 6 March.

Karahan, Fatih, Ben Pugsley and Ayşegül Şahin, 2015. "Understanding the 30-Year Decline in the Startup Rate: A General Equilibrium Approach," working paper.

Kleiner, Morris M., 2015. "Reforming Occupational Licensing Policies," Discussion Paper 2015-01, The Hamilton Project, The Brookings Institution, March.

Kleiner, Morris M. and Alan B. Krueger, 2013. "Analyzing the Extent and Influence of Occupational Licensing on the Labor Market," Journal of Labor Economics, 31, no. 2 (Part 2, April), pp. S173-S202.

Liang, James, Hui Wang and Edward P. Lazear, 2014. "Demographics and Entrepreneurship," NBER Working Paper No. 20506. 
Mankiw, N. Gregory, 2013. “A Carbon Tax that America Could Live With,” New York Times, 2 September.

McCaherty, Joshua D., 2014. "The Cost of Tax Compliance," Tax Policy Blog, The Tax Foundation, 11 September.

McLaughlin, Patrick A. and Richard Williams, 2014. "The Consequences of Regulatory Accumulation and a Proposed Solution,” Mercatus Center Working Paper no. 14-03.

Mulligan, Casey and Andrei Shleifer, 2005. "The Extent of the Market and the Supply of Regulation," Quarterly Journal of Economics, 120, no. 4, 1445-1473.

Murray, Charles, 2015. By the People: Rebuilding Liberty without Permission, Crown Forum.

National Taxpayer Advocate, 2012. Annual Report to Congress, 2012.

National Taxpayer Advocate, 2014. Annual Report to Congress, 2014.

Pastor, Lubos and Veronesi, Pietro, 2013. "Political Uncertainty and Risk Premia," Journal of Financial Economics, 110, no. 3 (December), 520-545.

Scott, Kenneth E. and John B. Taylor, editors, 2012. Bankruptcy Not Bailout: A Special Chapter 14, Hoover Institution Press.

Scott, Kenneth E., Thomas H. Jackson, and John B. Taylor, editors, 2015. Making Failure Feasible: How Bankruptcy Reform Can End Too Big to Fail, Hoover Institution Press.

Shleifer, Andrei, 2010. "Efficient Regulation," in Daniel P. Kessler, editor, Regulation vs. Litigation: Perspectives from Economics and Law, University of Chicago Press.

Shultz, George P., 2013. Issues on My Mind: Strategies for the Future. Hoover Institution Press.

Tabarrok, Alex and Tyler Cowen, 2015. "The End of Asymmetric Information," Cato Unbound: A Journal of Debate, 6 April at http://www.cato-unbound.org/2015/04/06/alex-tabarroktyler-cowen/end-asymmetric-information.

Taylor, John B., 2012. First Principles: Five Keys to Restoring America's Prosperity. W.W. Norton \& Company.

U.S. Department of Treasury Office of Economic Policy, 2015. "Occupational Licensing: A Framework of Policymakers," prepared with the President's Council of Economic Advisors and the U.S. Department of Labor, July.

Wiggins, Rosalind Z., Thomas Piontek and Andrew Metrick, 2014. "The Lehman Brothers Bankruptcy A: Overview," Yale Program on Financial Stability Case Study 2014-3A-V1.

World Bank, 2014. Doing Business 2015: Going Beyond Efficiency. Washington, DC. 
Figure 2. An Upward Drift in Policy-Related Economic Uncertainty

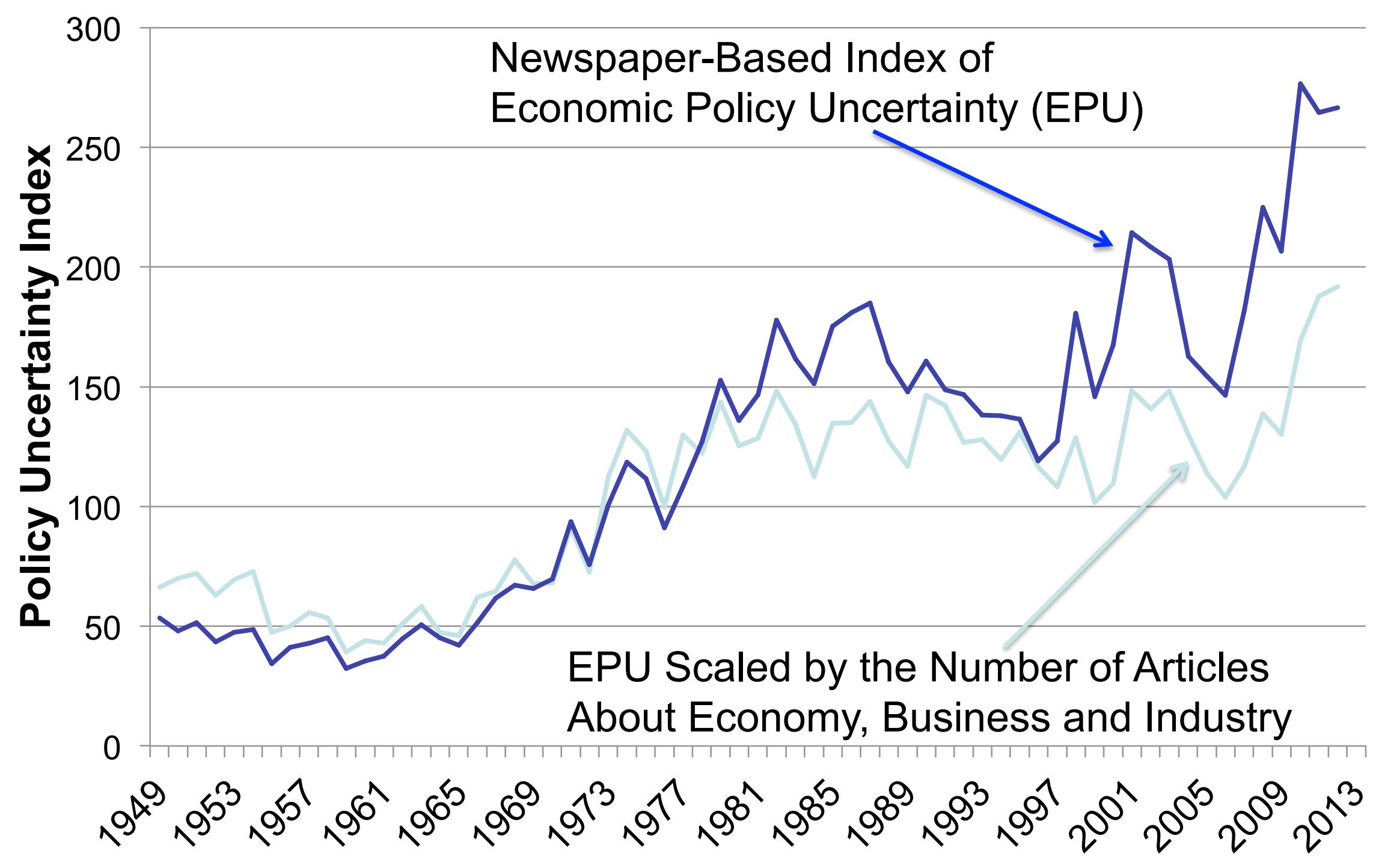

Source: Baker et al. (2014). Data are annual averages of monthly values from 1949 to 2012. 
Figure 3: Healthcare Policy Uncertainty Index, 1985 to 2014, Quarterly

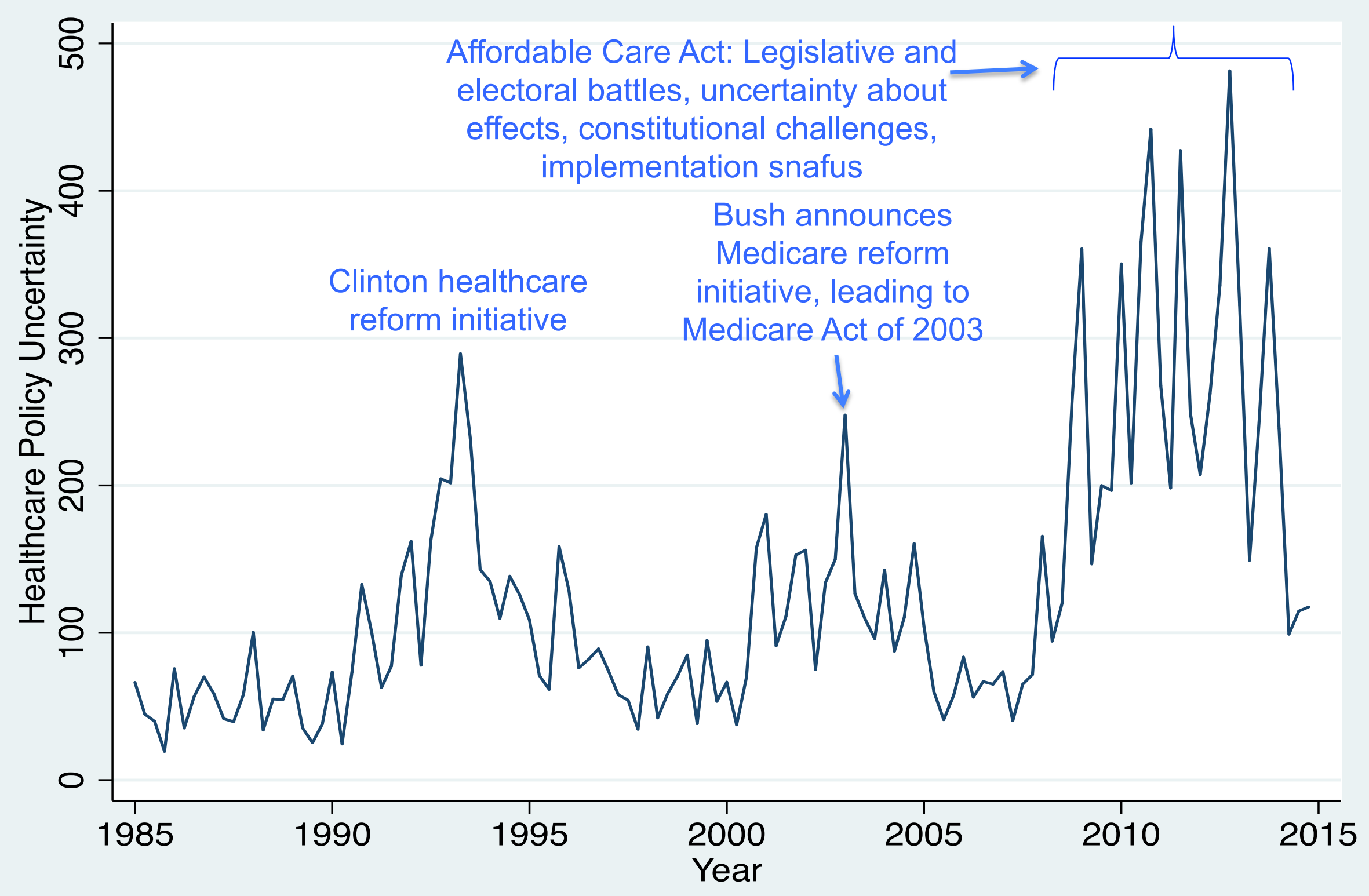

Notes: The index reflects the frequency of newspaper articles about economic policy uncertainty and healthcare policy matters, as indicated by terms like "healthcare," "hospital," "health insurance," and "Medicare." Data are from Baker, Blopm and Davis (2015) and are available and updated monthly at www.PolicyUncertainty.com. Normalized to a mean of 100 from 1985 to 2009. 


\section{Figure 4: Financial Regulation Uncertainty Index, 1985 to 2014, Quarterly}

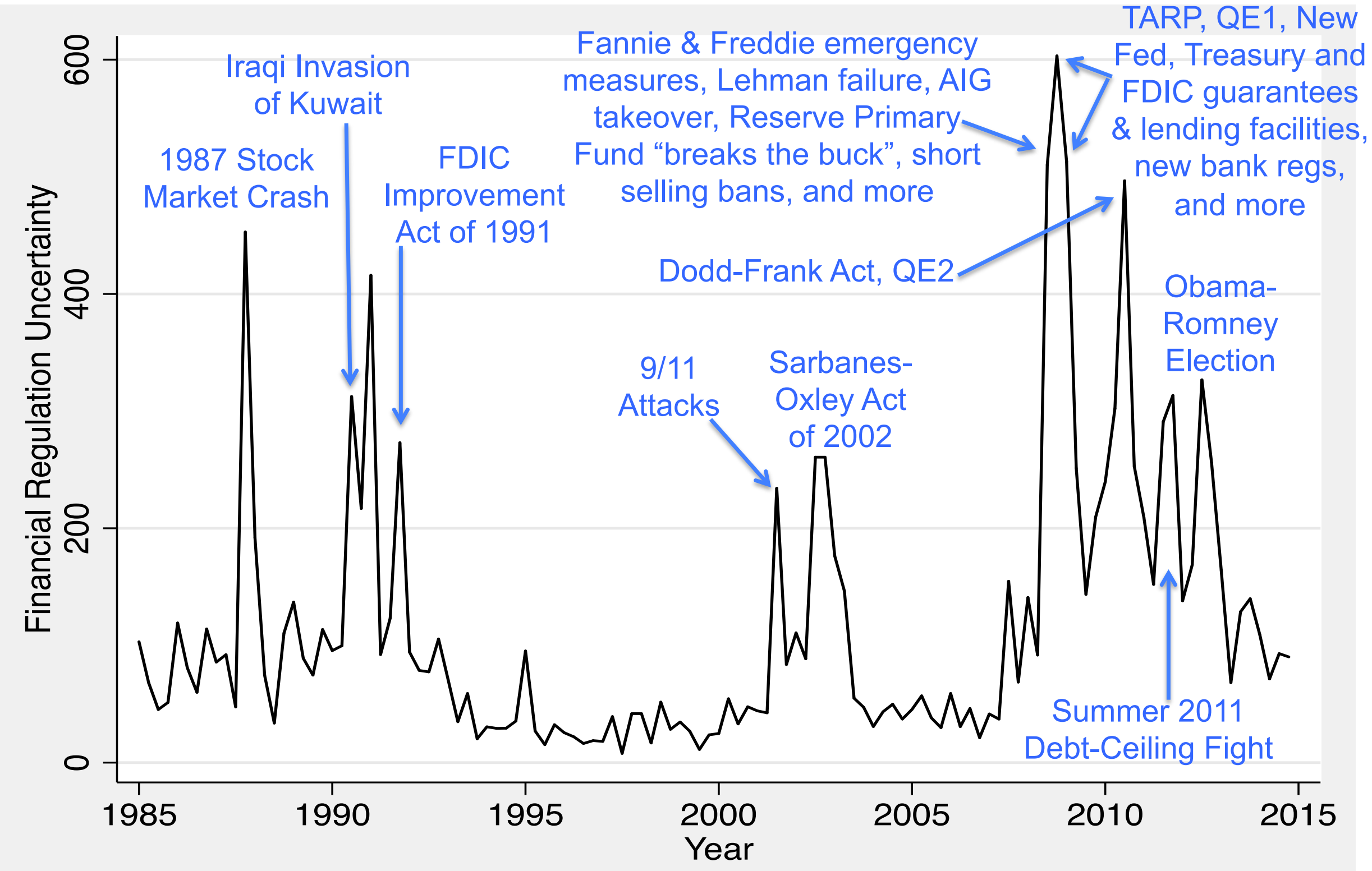

Notes: The index reflects the frequency of newspaper articles about economic policy uncertainty and financial regulatory matters, as indicated by terms like "bank(ing) supervision," "Glass-Steagall," and "Dodd-Frank." Data are from Baker, Bloom and Davis (2015) and are available and updated monthly at www.PolicyUncertainty.com. Normalized to a mean of 100 from 1985 to 2009. 


\section{Figure 5: Federal Tax Code Expirations Index, 1991-2013}

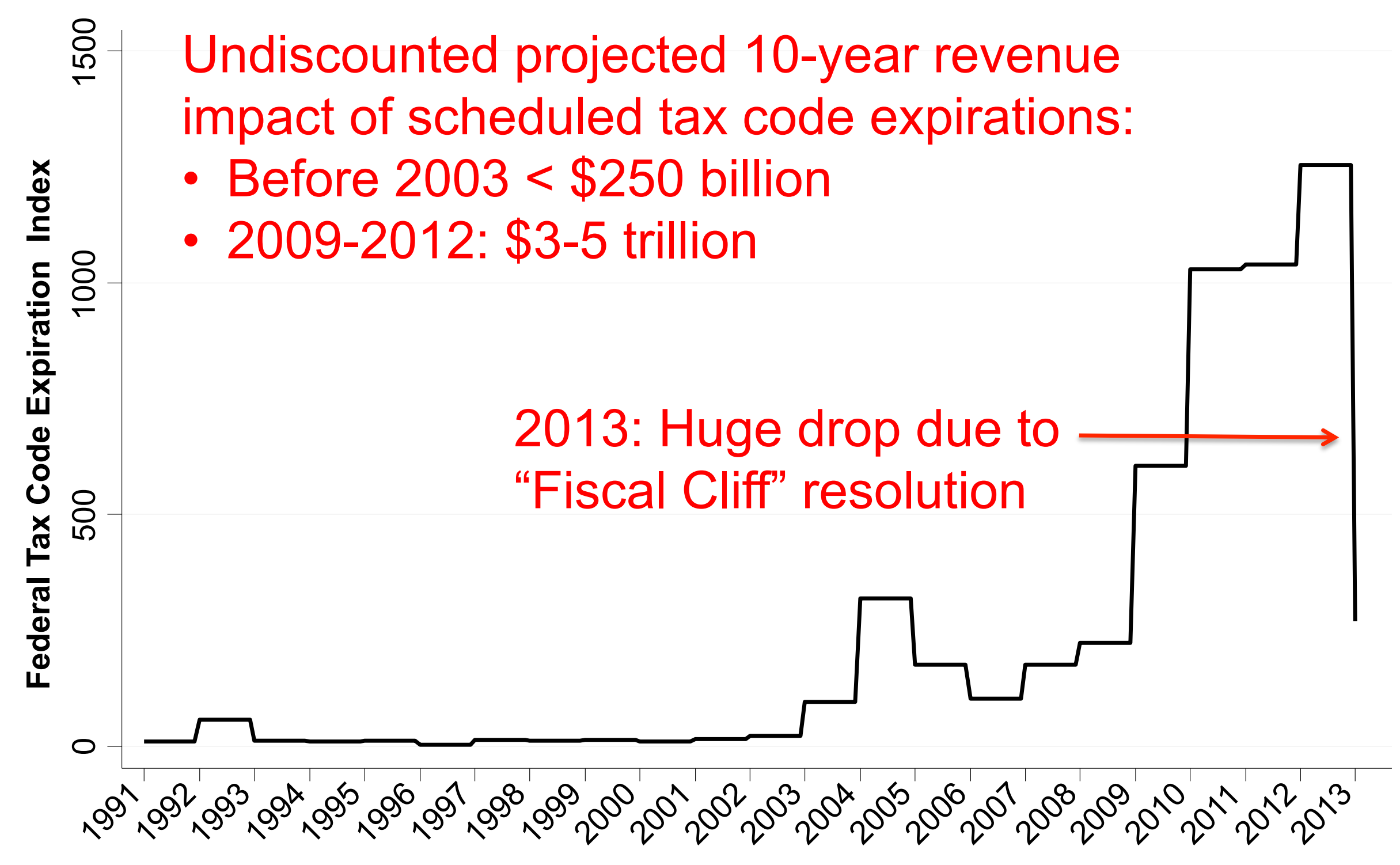

Notes: Based on Congressional Budget Office data on projected revenue effects of federal tax code provisions set to expire in the current calendar year and next ten years. For a given year, the index value is calculated as the discounted sum of projected revenue effects associated with expiring tax code provisions, using a discount factor of $0.5^{\wedge} \mathrm{T}$ applied to future revenue effects for $\mathrm{T}=0,1, \ldots 10$ years. Index normalized to a mean of 100 before 2010 . This chart is reproduced from earlier drafts of Baker, Bloom and Davis (2015). 
